\title{
Study on diseases prevalence in the selected areas emphasis on parasitic diseases of Pigeon
}

\author{
Akter MTD ${ }^{1 *}$, Sarder MJU1 ${ }^{1}$, Islam $\mathrm{MH}^{1}$, Islam $\mathrm{MR}^{1}$, Parvez $\mathrm{NH}^{2}$ and Alam $\mathrm{MN}^{3}$ \\ ${ }^{1}$ Department of Veterinary and Animal Sciences, Faculty of Agriculture, University of Rajshahi, \\ Bangladesh \\ 2 Department of Anatomy and Histology, Faculty of Veterinary and Animal Sciences, Hajee Danesh \\ Science and Technology University, Dinajpur \\ ${ }^{3}$ Eskayef Pharmaceuticals Limited, Dhaka, Bangladesh
}

\begin{abstract}
This experiment was carried out to determine the overall prevalence of pigeon diseases and especially emphasized on prevalence of parasitic diseases in study areas. During this study 45 farms were selected which have $>20$ pair of pigeon for commercial and $>10$ pair pigeon for traditional farm in the three-study area namely Rajshahi, Natore and Pabna district of Bangladesh. The data were collected from different farm within the study area through a questionnaire and interview schedule with the farm owners. During one year of study period a total Out of 3677 pigeon, positive case in cage of external parasites were 722 and internal parasite positives 114 from 263 fecal sample. The overall prevalence of gastrointestinal and external parasites in pigeon at northern Bangladesh is obtained. The infestation of lice Columbaecula columbae and fly Pseudolynchia canariensis were observed $18.08 \%$ and $1.55 \%$ respectively. The present study found two species of ectoparasites lice and fly. Diversity of ectoparasite in birds infestation may be depend on many factors, which may include home range, behavior, size and roosting habit of the host. The overall prevalence of gastrointestinal parasites in pigeon are founded that $43.34 \%$ in research area. Specific incidence was $22.81 \%$ in Ascariasis, $18.63 \%$ in Capilariasis and $1.90 \%$ in Raillietina parasite in pigeon. Ascaridia colombae is one of the most common $(22.81 \%)$ helminth species in pigeons in this study. The effect of breed of pigeon observed in present studies the highest in indigenous $(63.47 \%)$ and lowest exotic (36\%) prevalence of gastrointestinal parasite was observed. The specific percentages of Ascariasis, Capilariasis and Raillatina gastrointestinal parasites of pigeon were found $20 \% \& 31.74 \%$; $14 \% \& 30.15 \%$ and $2 \% \& 1.58 \%$ in exotic \& indigenous breed, respectively. In the present study, there is a relation between the occurrence of gastrointestinal parasitic infections with the age of the pigeons which showed that high prevalence in adults $(50 \%)$ and compare to young $(22.22 \%)$. but it was statistically significant $(P>0.05)$. In relation with farming system the gastrointestinal parasitic incidence of pigeon was observed in modern and tradition farming system, the highest incidence was $71.16 \%$ in traditional \& lowest $31.14 \%$ in modern farming. When observed specifically in Ascariasis, Capillariasis \& Raillietina were $16.39 \%$ \& $37.41 \% ; 13.11 \% \& 31.25 \%$ and $1.63 \% \& 2.5 \%$ in modern \& traditional, respectively. The effect of regions on the prevalence of gastrointestinal parasites in pigeon was observed in Pabna (68.32\%), Natore (57.84\%) and Rajshahi (33.33\%). The specific percentages of Ascariasis, Capilariasis and Raillatina gastrointestinal parasites of pigeon were $18.18 \%, 33.33 \%$ \& $26.31 \% ; 14.54 \%, 33.33 \%$ \& $23.38 \%$ and $0.606 \%, 1.66 \% \& 7.89 \%$ in Rajshahi, Pabna and Natore, respectively.
\end{abstract}

Key words: Diseases, prevalence, parasitic diseases and Pigeon

\section{Introduction}

Pigeon are kept in backyards or commercial production systems in most areas of the world. The local birds like pigeon do not only provide for the protein requirement of the family on occasions but also act as income generation source. Pigeon farming is very interesting, profitable and it is a very familiar domestic bird. The contributions of pigeon have not yet been considered in relation to the contribution of livestock sub-sector and whole poultry production though the pigeons provide alternative source of animal protein. Parasitic diseases are global problems including Bangladesh and are considered as major obstacles in the health and product performance of animals. These diseases may be due to the endo-parasites that live inside the body, or by the ecto-parasites which attack the body surface of animals and humans. Helminth parasites causes severe disease of economic and public health significance affecting animal and human health, resulting in decrease in egg production and heavy mortality [1]. During farming of pigeon there are many constraints which faced by the farmer or pigeon holder. Among them diseases prevalence which most importantly affect the productivity, growth performance and income source. Pigeon farming is a profitable business with less investment and labors but several emerging diseases cause obstacles to the pigeon sector and cause huge damage to the farmers and also causes significant 
economic losses. Among the prevalent diseases parasitic infestation is one of them. Various parasites affect the growth, development and productivity of birds. Like other microbes, it also harbors various parasitic diseases, among these gastrointestinal helminthes are the most deleterious parasites responsible for occurrence of clinical and subclinical parasitic condition [2]. Pigeons can cause contamination of surroundings with their droppings and can carry many parasites and pathogens to different flocks. Pigeon can be parasitized by a wide variety of ecto and endo-parasites. Due to an increased risk of exposure, parasites can lead to serious problems or even to death in birds kept for prolonged periods. A good knowledge about the parasitic disease of pigeons would aid in the development of possible control measures, which may help in enhancing its survival and complement efforts towards public enlightenment. However, there is a huge literature on avian medicine including parasitic diseases but little has been documented about the parasites in pigeons.

\section{Materials and methods}

This experiment was conducted at City corporation of Rajshahi (15 farms), Sadar upazilas of Natore (15 farms) and Pabna district (15 farms) in North-western Bangladesh. During this study 45 farms were selected which have $>20$ pair of pigeon and on their availability.

\section{Data collection}

The data were collected from the selected pigeon farm through a questionnaire and by interview schedule directly from the farm owners. Sample were collected from the selected farm by own visit in a regular interval.

\section{Sampling procedure}

Both the ecto-parasite (lice and mites) and endo-parasite (round and tape worms) are identified from selected pigeon by preparing permanent slide of these species. Fecal samples have collected from pigeons. The feces were collected in air tight containers and were observed microscopically for presence of eggs of endo-parasites. Fecal samples collected from different places are fixed by mixing with sufficient quantity of normal saline. Microscopical examination of feces was carried out by direct smear method. For the presence of proglottids of cestodes faeces was also grossly examined. Direct smear, this method was done by mixing a drop of tap water with bit of feces using an applicator stick on glass microscopic slide covered with slip and examined at low and high power.

\section{Statistical analysis:}

Analysis of data by some computer packages like SPSS version, 21 and compared using Analysis of variance (ANOVA) by Duncan Multiple Range Test (DMRT). Data were presented as Mean \pm SE. $P<0.05$ was considered as significant.

\section{Results}

The overall prevalence of gastrointestinal and external parasites in pigeon at northern Bangladesh is obtained Figure 01 . Out of 3677 pigeon, positive case in cage of external parasites were 722 and internal parasite positives 114 from 263 fecal sample.

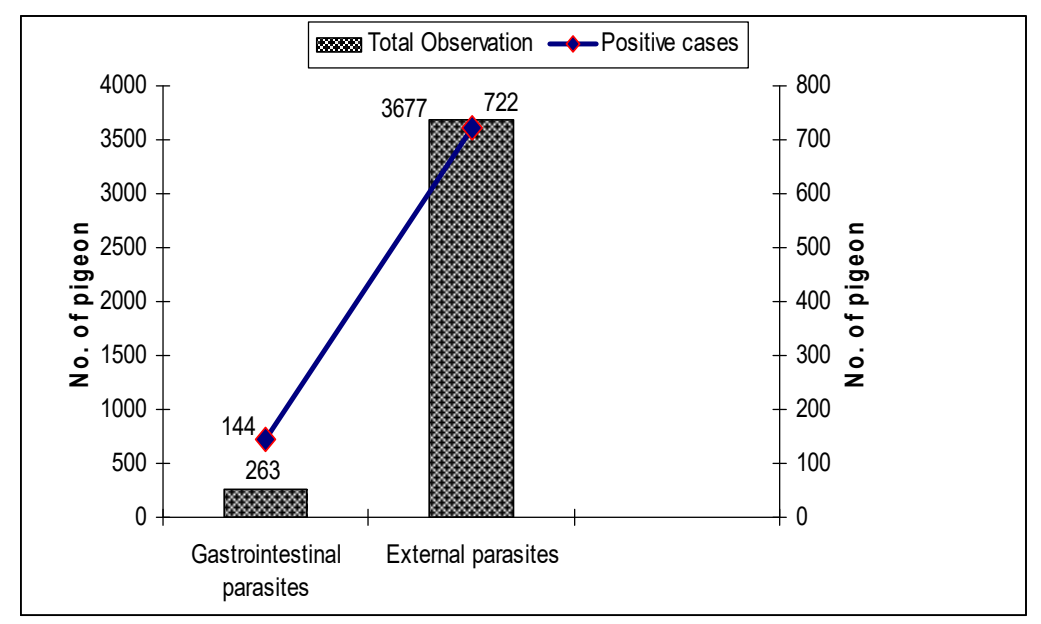

Figure 01: Prevalence of gastrointestinal and external parasites in pigeon at northern Bangladesh. 
The infestation of lice Columbaecula columbae and fly Pseudolynchia canariensis were observed $18.08 \%$ and $1.55 \%$ respectively (Figure 02 ).

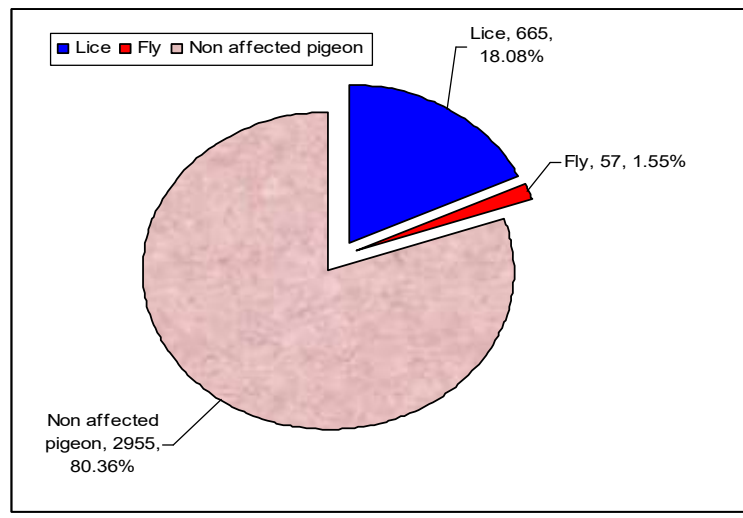

Figure 02: Infestation of lice and fly in pigeon at study area.

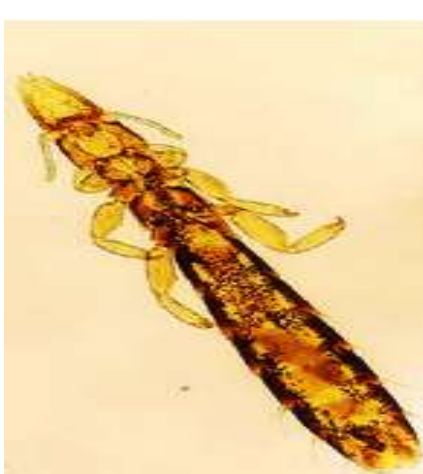

Figure 03- Pigeon lice: Columbaecula columbae

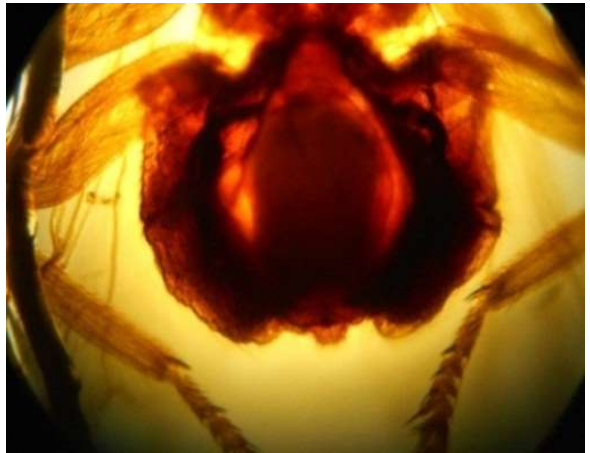

Figure 04- Pigeon fly: Pseudolynchia canariensis

The overall prevalence of gastrointestinal parasites in pigeon were shown in Table-01 \& Figure-05. It was founded that overall $43.34 \%$ gastrointestinal parasite disease noted in research area. Specific incidence was $22.81 \%$ in Ascariasis, $18.63 \%$ in Capilariasis and $1.90 \%$ in Raillietina parasite in pigeon (Table-01).

\section{Table 01: The overall prevalence of gastrointestinal parasites in pigeon at northern Bangladesh}

\begin{tabular}{|l|l|l|l|}
\hline Name of Parasites & No. of Fecal Sample & Positive case & $\%$ of infection \\
\hline Ascariasis & \multirow{3}{*}{263} & 60 & $22.81 \%^{\mathrm{a}}$ \\
\cline { 3 - 4 } Capillariasis & & 49 & $18.63 \%^{\mathrm{a}}$ \\
\cline { 3 - 4 } & & 5 & $1.90 \%^{\mathrm{b}}$ \\
\hline Raillietina & 263 & 114 & $43.34 \%$ \\
\hline
\end{tabular}

Values are percentage $(\%),\left({ }^{a b}\right)$ superscript values in column differ significantly $(P<0.05)$ with each other 


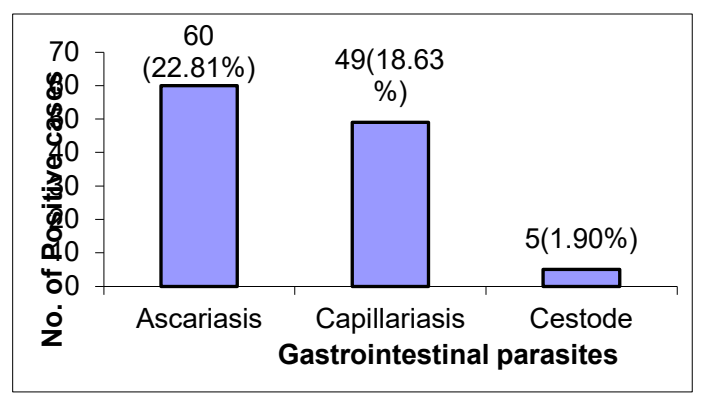

Figure 05: Infection of gastrointestinal parasites in pigeon.

The effect of Breed (exotic and indigenous) on the prevalence of gastrointestinal parasites in pigeon was shows in Table 02 \& Figure 06. The highest and lowest prevalence of gastrointestinal parasite was observed in indigenous (63.47\%) and exotic (36\%). The specific percentages of Ascariasis, Capilariasis and Raillatina gastrointestinal parasites of pigeon were $20 \% \& 31.74 \% ; 14 \% \& 30.15 \%$ and $2 \% \& 1.58 \%$ in exotic \& indigenous breed, respectively.

Table 02: Effect of breed on gastrointestinal parasites in pigeon

\begin{tabular}{|l|l|l|l|l|}
\hline Breed & No. of sample & Name of parasites & No. of case & \% of infection \\
\hline \multirow{4}{*}{ Exotic } & \multirow{4}{*}{200} & Ascariasis & 40 & $20 \%$ \\
\cline { 2 - 5 } & Capilariasis & 28 & $14 \%$ \\
\cline { 2 - 5 } & & Raillietina & 4 & $2 \%$ \\
\cline { 2 - 5 } & Total & $\mathbf{7 2}$ & $\mathbf{3 6 \%}$ \\
\hline \multirow{4}{*}{ Indigenous } & Ascariasis & 20 & $31.74 \%$ \\
\cline { 2 - 5 } & \multirow{3}{*}{63} & Capilariasis & 19 & $30.15 \%$ \\
\cline { 2 - 5 } & Raillietina & 1 & $1.58 \%$ \\
\cline { 2 - 5 } & & Total & $\mathbf{4 0}$ & $\mathbf{6 3 . 4 7 \%}$ \\
\hline
\end{tabular}

Values are percentage $(\%),\left({ }^{a b}\right)$ superscript values in column differ significantly $(P<0.05)$ with each other.

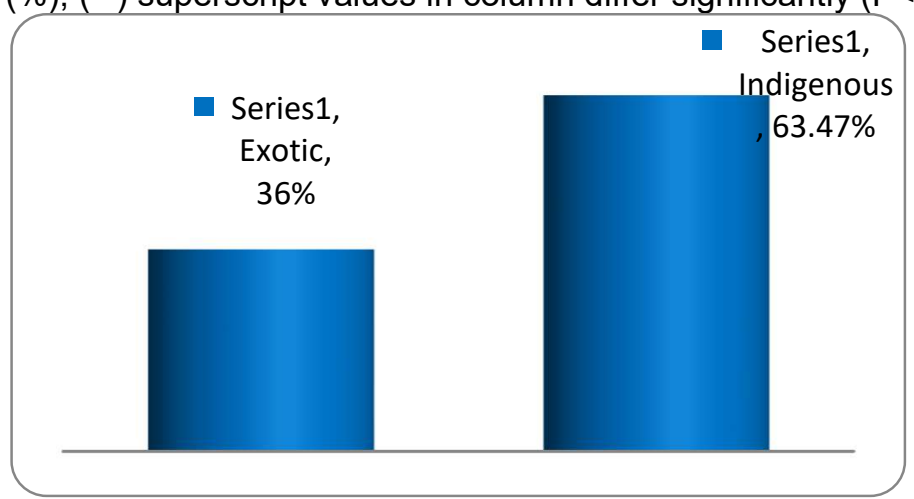

Figure 06: Effect of Breed on gastrointestinal parasites in pigeon

The effect of age of pigeon on the prevalence of gastrointestinal parasites was shows in Table 03. The highest and lowest prevalence was observed in adult (50\%) and young $(22.22 \%)$. The specific percentages of Ascariasis, Capillariasis and Raillietina gastrointestinal parasites of pigeon were $9.52 \%$ \& $27 \% ; 12.69 \% \& 20.5 \%$ and $0 \% \& 2.5 \%$ in young \& adult, respectively. 
Table 03: Age wise prevalence of parasites in pigeon

\begin{tabular}{|c|c|c|c|c|}
\hline Age & No. of sample & $\begin{array}{l}\text { Name of } \\
\text { parasites }\end{array}$ & No. of case & $\%$ of infection \\
\hline \multirow{4}{*}{ Young } & \multirow{4}{*}{63} & Ascariasis & 10 & $9.52 \%$ \\
\hline & & Capilariasis & 12 & $12.69 \%$ \\
\hline & & Raillietina & 0 & $0 \%$ \\
\hline & & Total & 22 & $22.22 \%^{b}$ \\
\hline \multirow{4}{*}{ Adult } & \multirow{4}{*}{200} & Ascariasis & 50 & $27 \%$ \\
\hline & & Capilaariasis & 37 & $20.5 \%$ \\
\hline & & Raillietina & 5 & $2.5 \%$ \\
\hline & & Total & 92 & $50 \% \%^{a}$ \\
\hline
\end{tabular}

Values are percentage $(\%),\left({ }^{a b}\right)$ superscript values in column differ significantly $(P<0.05)$ with each other The gastrointestinal parasitic incidence of pigeon was observed in modern and tradition farming system, the highest incidence was $71.16 \%$ in traditional \& lowest $31.14 \%$ in modern farming (Table 04 and Figure 07). When observed specifically in Ascariasis, Capillariasis \& Raillietina were $16.39 \%$ \& $37.41 \% ; 13.11 \%$ \& $31.25 \%$ and $1.63 \%$ \& $2.5 \%$ in modern \& traditional, respectively.

Table 04: Effect of farming system on prevalence of gastrointestinal parasites in pigeon

\begin{tabular}{|c|c|c|c|c|}
\hline Farm types & $\begin{array}{l}\text { No. of fecal } \\
\text { sample }\end{array}$ & Name of parasites & No.of case & $\%$ of infection \\
\hline \multirow{4}{*}{ Modern } & \multirow{4}{*}{183} & Ascariasis & 30 & $16.39 \%$ \\
\hline & & Capillariasis & 24 & $13.11 \%$ \\
\hline & & Raillietina spp. & 3 & $1.63 \%$ \\
\hline & & Total & 57 & $31.14 \%{ }^{b}$ \\
\hline \multirow{4}{*}{ Traditional } & \multirow{4}{*}{80} & Ascariasis & 30 & $37.41 \%$ \\
\hline & & Capilariasis & 25 & $31.25 \%$ \\
\hline & & Raillietina & 2 & $2.5 \%$ \\
\hline & & Total & 57 & $71.16 \%^{\mathrm{a}}$ \\
\hline
\end{tabular}

Values are percentage $(\%),\left({ }^{\mathrm{ab}}\right)$ superscript values in column differ significantly $(P<0.05)$ with each other

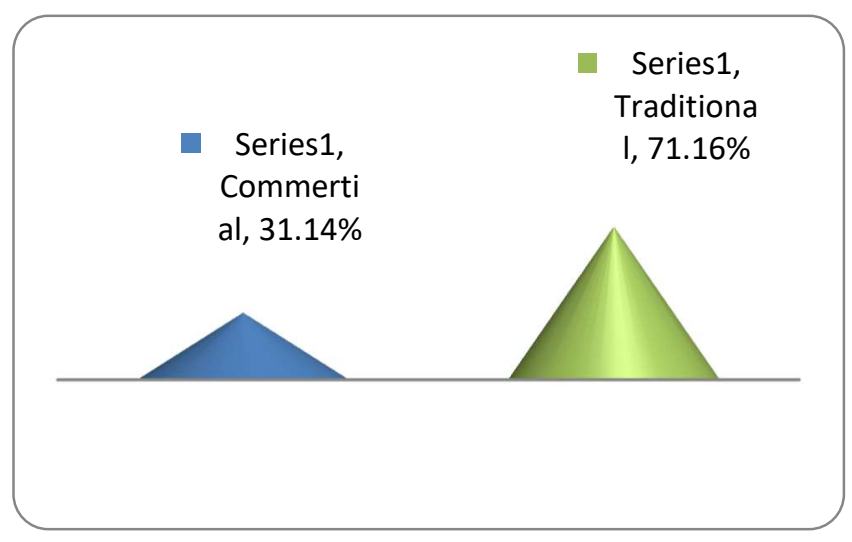

Figure 07: Farming system on prevalence of gastrointestinal parasites in pigeon

The effect of regions on the prevalence of gastrointestinal parasites in pigeon was shows in Table $05 \&$ Figure 08. The highest, lowest and other prevalence was observed in Pabna (68.32\%), Natore (57.84\%) and Rajshahi $(33.33 \%)$. The specific percentages of Ascariasis, Capilariasis and Raillatina 
gastrointestinal parasites of pigeon were $18.18 \%, 33.33 \% \& 26.31 \% ; 14.54 \%, 33.33 \% \& 23.38 \%$ and $0.606 \%, 1.66 \%$ \& $7.89 \%$ in Rajshahi, Pabna and Natore, respectively.

Table 05: Effect of regions on prevalence of gastrointestinal parasites in pigeon

\begin{tabular}{|c|c|c|c|c|}
\hline Area & No. of sample & $\begin{array}{l}\text { Name of } \\
\text { parasites }\end{array}$ & No. of case & $\%$ of infection \\
\hline \multirow{4}{*}{ Rajshahi } & \multirow{4}{*}{165} & Ascariasis & 30 & $18.18 \%$ \\
\hline & & \begin{tabular}{|l|} 
Capilariasis \\
\end{tabular} & 24 & $14.54 \%$ \\
\hline & & Raillietina & 1 & $0.606 \%$ \\
\hline & & Total & 55 & $33.33 \%^{c}$ \\
\hline \multirow{4}{*}{ Pabna } & \multirow{4}{*}{60} & Ascariasis & 20 & $33.33 \%$ \\
\hline & & Capilariasis & 20 & $33.33 \%$ \\
\hline & & Raillatina & 1 & $1.66 \%$ \\
\hline & & Total & 41 & $68.32 \%^{\mathrm{a}}$ \\
\hline \multirow{4}{*}{ Natore } & \multirow{4}{*}{38} & Ascariasis & 10 & $26.31 \%$ \\
\hline & & Capilariasis & 9 & $23.38 \%$ \\
\hline & & Raillietina & 3 & $7.89 \%$ \\
\hline & & Total & 22 & $57.84 \%^{\mathrm{b}}$ \\
\hline
\end{tabular}

Values are percentage $(\%),\left({ }^{a b c}\right)$ superscript values in column differ significantly $(\mathrm{P}<0.05)$ with each other

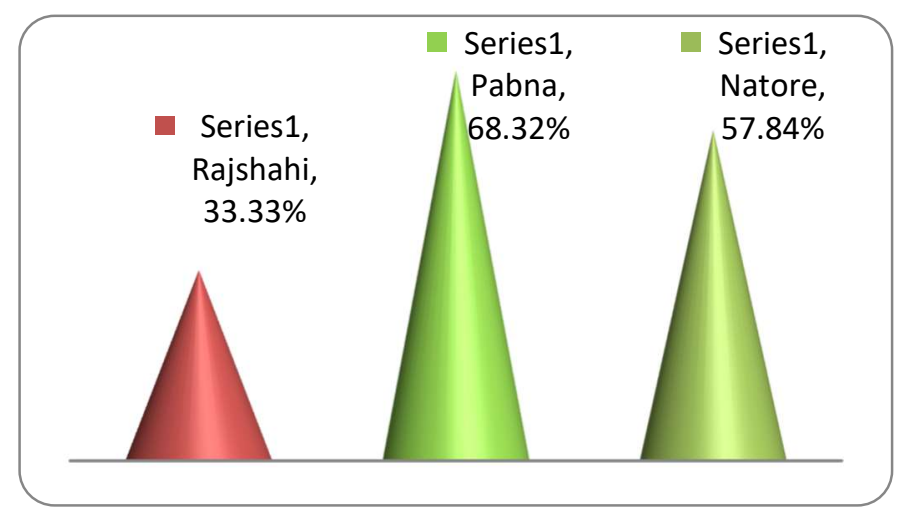

Figure 08: Regions on prevalence of gastrointestinal parasites in pigeon

The present study showed that, helminthes were significantly more prevalent in adults than in young. Indigenous breeds are more prevalent in parasitic infection than exotic breeds. In traditional farming system the rate of infection is more than commercial farming system among three districts Rajshahi, Natore, Pabna the rate of infection is high in Pabna then Natore then Rajshahi. 


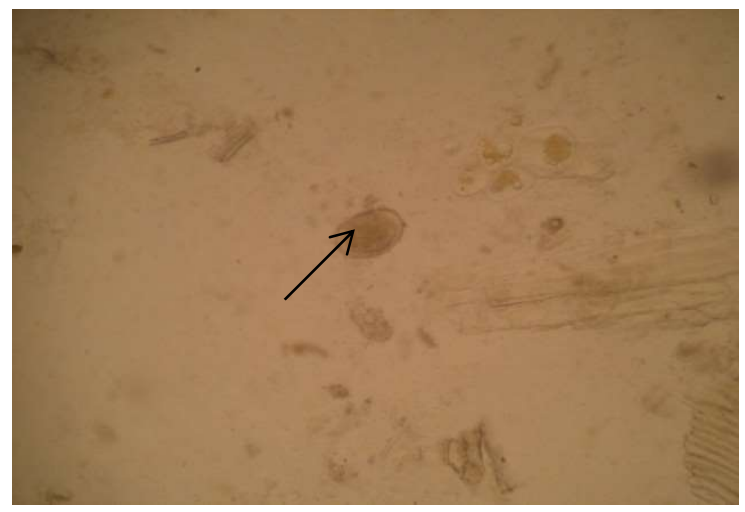

Figure 09: Egg of Ascaridia sp. indicating the arrow

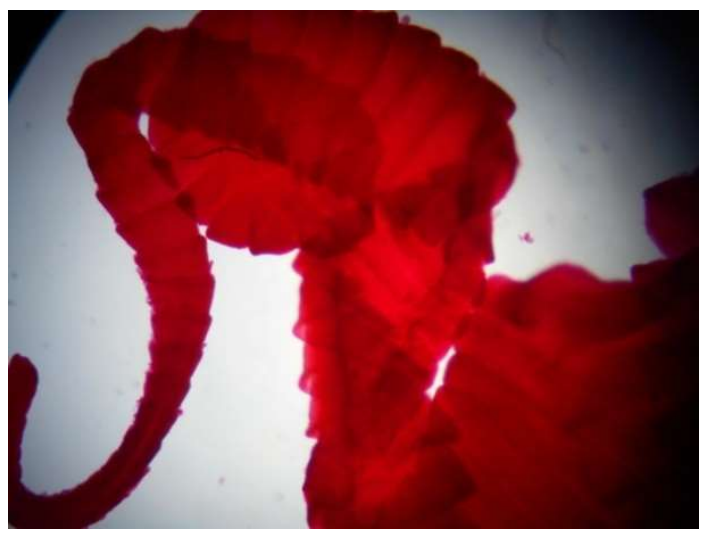

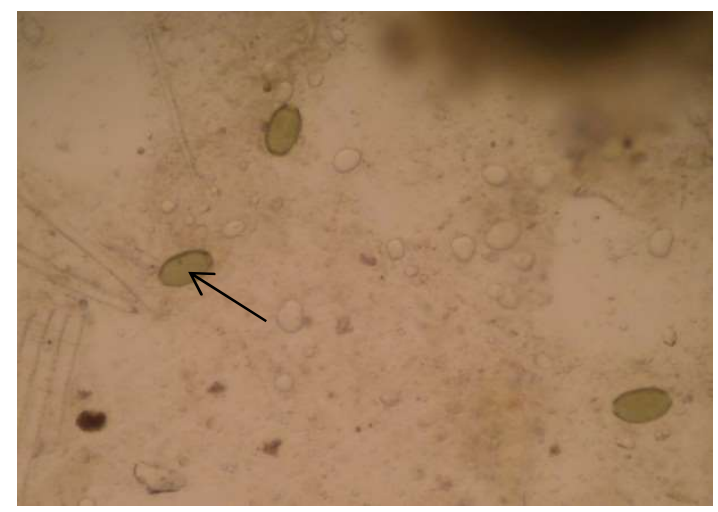

Figure 10: Egg of Capillaria sp. indicating the arrow

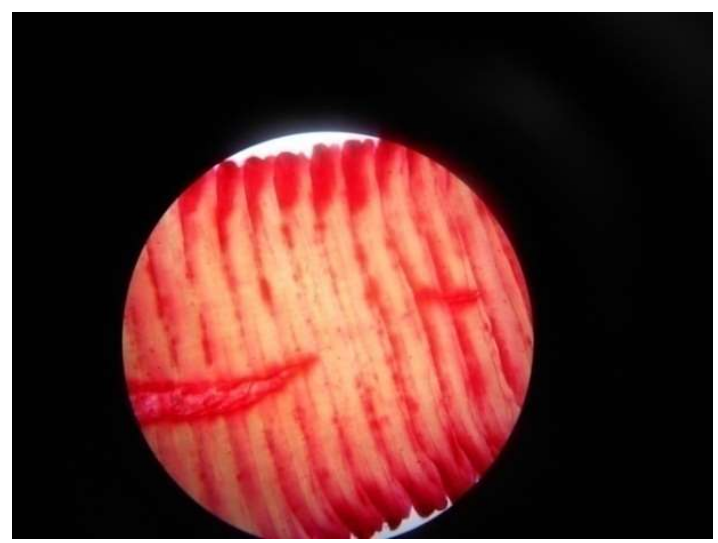

Figure 11: Railleitina spp. of pigeon (Cestode)

\section{Discussion}

As causes of parasitic infestation found within those farm and pigeon loft, the owner does not use regular doses of anthelmintic and irregular cleaning of pigeon nest. Other infection occurs for their unhygienic management. These area farmers haven't enough knowledge about pigeon rearing and management. Out of 3677 pigeon, positive case in cage of external parasites were 722 and internal parasite positives 114 from 263 fecal sample. The overall prevalence of gastrointestinal and external parasites in pigeon at northern Bangladesh is obtained Figure 01. No study has been carried out on the ecto-parasites of pigeon in the study areas. So, this study provides helpful data on infestation rate to ectoparasites of pigeons in this area. The infestation of lice Columbaecula columbae and fly Pseudolynchia canariensis were observed $18.08 \%$ and $1.55 \%$ respectively (Figure 02 ). Jahantigh and his associates, recorded two species of ectoparasites were identified (tick and lice) [3]. The specie of Argas reflexus (tick) were found on walls and seams of cubbyholes and C. columbae were found on quill feathers of wing and tail. On the other hand the present study found two species of ecto-parasites lice and fly. Diversity of ecto-parasite in birds infestation may be depend on many factors, which may include home range, behavior, size and roosting habit of the host. Some of the results of this study agreed and some are disagreed with the findings of other studies performed in some parts of the world. In a study researcher found two ecto-parasites on the pigeon both were lice species namely, Columbicola columbae and Chelopistes meleagridis, and occurred at the prevalence of $58 \%$ and $14 \%$, respectively [4]. In another study identified four, five and seven species of ecto-parasites $[5,6,7]$ but in present study found two species of ecto-parasites. The overall prevalence of gastrointestinal parasites in pigeon are founded that 
43.34\% in research area. Specific incidence was $22.81 \%$ in Ascariasis, $18.63 \%$ in Capilariasis and $1.90 \%$ in Raillietina parasite in pigeon (Table 01). Ascaridia colombae is one of the most common $(22.81 \%)$ helminth species in pigeons in this study. Heavy infection of Ascaridia colombae causes mild catarrhal enteritis, obstruction, dilation and mild to necrotic ulcer in small intestine. The prevalence of Ascaridia sp., Capillaria sp. and Raillietina sp., were 30,10 and $28 \%$, respectively also found by Tarikul [8].

In the present study Raillietina showed low prevalence $(1.90 \%)$. It was lower compare with the other studies conducted by three researchers where they found $9.0 \%, 5.19 \%$ and $25 \%$ prevalence of Raillietina echinobothridia respectively $[9,10,5]$. The effect of breed of pigeon observed in present studies the highest and lowest prevalence of gastrointestinal parasite was observed in indigenous $(63.47 \%$ ) and exotic (36\%). The specific percentages of Ascariasis, Capilariasis and Raillatina gastrointestinal parasites of pigeon were found $20 \% \& 31.74 \% ; 14 \% \& 30.15 \%$ and $2 \% \& 1.58 \%$ in exotic \& indigenous breed, respectively. In the present study, there is a relation between the occurrence of gastrointestinal parasitic infections with the age of the pigeons which showed that high prevalence in adults (50\%) and compare to young $(22.22 \%)$. but it was statistically significant $(P>0.05)$. Another study recorded a relation between the occurrence of gastrointestinal parasitic infections with the age of the pigeons which showed that high prevalence in adults (75\%) when compare to squabs $(64.2 \%)$ but it was not statistically significant $(\mathrm{P}>0.05)$ [9]. Prevalence of Ascaridia and Capillaria sp infections were in association with age of pigeon found in present study is supported the previous records of the occurrence of Ascaridia galli (32\%) and Capillaria sp infections (26\%) in pigeons [2]. In relation with farming system the gastrointestinal parasitic incidence of pigeon was observed in modern and tradition farming system, the highest incidence was $71.16 \%$ in traditional \& lowest $31.14 \%$ in modern farming. When observed specifically in Ascariasis, Capillariasis \& Raillietina were $16.39 \%$ \& $37.41 \% ; 13.11 \%$ \& $31.25 \%$ and $1.63 \%$ \& $2.5 \%$ in modern \& traditional, respectively. Usually, pigeon is reared in semi-scavenging or scavenging system in our country. Due to constant contact with the soil these birds serve as reservoir for soil transmitted helminthes. Especially in free-range birds' parasitic infestations are often neglected though they are causing reduced growth and higher mortality. The effect of regions on the prevalence of gastrointestinal parasites in pigeon was observed in Pabna (68.32\%), Natore (57.84\%) and Rajshahi (33.33\%). The specific percentages of Ascariasis, Capilariasis and Raillatina gastrointestinal parasites of pigeon were $18.18 \%, 33.33 \%$ \& $26.31 \% ; 14.54 \%, 33.33 \%$ \& $23.38 \%$ and $0.606 \%, 1.66 \%$ \& $7.89 \%$ in Rajshahi, Pabna and Natore, respectively.

\section{Conclusion}

According to the results and discussion we concluded that in concern with parasitic diseases Ascariasis and lice infestation was more prevalent. No study has been carried out on the ectoparasites of pigeon in the study areas. So, this study provides helpful data on infestation rate to ectoparasites of pigeons in future. Finally, proper hygienic management and control or preventive measures need much more attention for betterment of farming of pigeon.

\section{References}

1. Umaru, G. A., Bello, O. A., Abubakar, Y. U., Umar, Y. A., Adamu, N. B., and Adamu, S. G. (2017), Prevalence of helminth parasites of domestic pigeons (Columba livia) in Jalingo Metropolis, Taraba State, Nigerian Journal of Parasitology ISSN 11174145 Volume 38[1] .Volume 1 Issue 1.

2. Ghosh KK, Islam MS, Sikder S, et al. (2014), Prevalence of ecto and gastrointestinal parasitic infections of pigeon at Chittagong metropolitan area, Bangladesh. J Adv Parasitol. 2014; 1(1):9-11.

3. M. Jahantigh, R. Esmailzade dizaji, Y. Teymoori, (2016), Prevalence of external parasites of pigeon in Zabol, southeast of Iran, J Parasit Dis (Oct-Dec 2016) 40(4):1548-1551.

4. Laku CB, Onwuteaka JN and Amuzie CC (2018) Ecto-Parasites and Intestinal Helminth Community of Domesticated Pigeons (Columba livia) of Trans-Amadi Abattoir, Port Harcourt, Nigeria, Journal of Gastroenterology Forecast.

5. Syed Mehmood, Nawab Nashiruddullah, Jafrin A. Ahmed, Sanku Borkataki (2019), Parasitic affections of domesticated pigeons (Columba livia) in Jammu, India, Annals of Parasitology 2019, 65(1), 53- 64. 
6. O. Kolomak, O. V. Kruchynenko (2017), Bird Lice (Mallophaga, Philopteridae, Menoponidae) of domestic pigeons on specialized pigeon breeding farms in poltava, Vestnik zoologii, 51(6): 487-492, 2017, DOI 10.1515/vzoo-2017-0058.

7. M Saikia, K Bhattacharjee, PC Sarmah, DK Deka and D Mushahary (2017), Prevalence of ectoparasitic infestation of pigeon (Columba livia domestica) in Assam, India, Journal of Entomology and Zoology Studies 5(4): 1286-1288.

8. Tarikul Islam, Salah Uddin Ahmad, Mamun Ur Rahman, Amir Hossain, Mahfuz Rahman Adnan, Mustaq Ahmad, Mowdudul Hasan Talha and Matiur Rahman,( 2017). Prevalence of gastro-intestinal parasitic infestation of pigeon at Sylhet district in Bangladesh. Asian J. Anim. Sci., 11: 189-193.

9. Sivajothi S, Sudhakara Reddy, (2015), A study on the gastro intestinal parasites of domestic pigeons in YSR Kadapa district in Andhra Pradesh, India, Journal of Dairy, Veterinary \& Animal Research, Volume 2 Issue 6 - 2015.

10. Punya Ram Sukupayo (2018), A Study on the Gastro Intestinal Parasites of Pigeons of Suryabinayak, Bhaktapur, Anusheelan Year 10, No. 9 Shrawan 2075 B. S. 